\title{
LESZEK ROJOWSKI \\ Doskonalenie współpracy pomiędzy duchowieństwem a świeckimi w parafialnych radach duszpasterskich
}

Przed trzema laty Kościół w Polsce podjął realizację nowego, trzyletniego Programu duszpasterskiego: Kościół domem i szkoła komunii. Wśród jego kilku zasadniczych celów wskazano na odnowę i wzmocnienie struktur komunijnych we wspólnotach kościelnych ${ }^{1}$. Dla osiągnięcia tego celu podejmowano w minionych dwóch latach przedsięwzięcia zmierzające m.in. do tworzenia i ożywiania działalności parafialnych rad duszpasterskich i ekonomicznych ${ }^{2}$. W obecnym, trzecim roku Programu, skupionego wokół hasła: Być sola ziemi, podejmuje się m.in. działania zmierzające do doskonalenia współpracy pomiędzy duchowieństwem oraz świeckimi w tego typu strukturach ${ }^{3}$. Właśnie ta tematyka, odniesiona do parafialnej rady duszpasterskiej (dalej: PRD), stanowi przedmiot refleksji niniejszego opracowania.

Punktem wyjścia dla analizowanej problematyki będzie nieco szersze ukazanie teologicznego fundamentu współpracy i współdziałania w ramach PRD. Nie ulega bowiem wątpliwości, że znajomość i właściwe rozumienie Kościoła

Leszek R O J O W S K I, ks. dr, prodziekan Wydziału Teologicznego - Sekcja w Tarnowie Uniwersytetu Papieskiego Jana Pawła w Krakowie, prorektor i wykładowca teologii pastoralnej w Wyższym Seminarium Duchownym w Tarnowie, e-mail: lrojowski@tarnow.opoka.org.pl

${ }^{1}$ K. Ka n to w s ki, S. S t u łk ow s k i: W komunii z Bogiem. W: Komisja Duszpasterstwa Konferencji Episkopatu Polski: $W$ komunii z Bogiem. Kościót domem i szkoła komunii. Program duszpasterski Kościoła w Polsce na lata 2010-2013. Red. S. S t u ł k o w s k i. Poznań 2010 s. 16.

${ }^{2}$ S. G ą d e c k i: Stowo wstęne. W: Komisja Duszpasterstwa Konferencji Episkopatu Polski: Kościół naszym domem. Kościół domem i szkoła komunii. Program duszpasterski Kościoła w Polsce na lata 2010-2013. Red. S. Stułkowski. Poznań 2011 s. 9-10.

${ }^{3}$ S. S t u łk ow s ki: Być sola ziemi. W: Komisja Duszpasterstwa Konferencji Episkopatu Polski: Być sola ziemi. Kościól domem i szkoła komunii. Program duszpasterski kościoła w Polsce na lata 2010-2013. Red. S. S t u ł k o w s k i. Poznań 2012 s. 22. 
odgrywa kluczową rolę w budowaniu dobrze funkcjonujących rad duszpasterskich. W kolejnym punkcie zostaną przedstawione niektóre szczegółowe kwestie, w których ujawniają się trudności we współdziałaniu duchownych i świeckich. W ostatniej części zostaną wskazane sposoby ich przezwyciężania, będące jednocześnie możliwościami doskonalenia współpracy.

\section{Fundamenty współpracy w parafialnych radach duszpasterskich}

Rady duszpasterskie w parafiach działają w oparciu o statuty bądź regulaminy wydawane przez biskupa diecezjalnego. Wynika to z rozporządzenia kan. 536 dedykowanego PRD. Normy prawnie zasadniczo nie dostarczają teologicznych uzasadnień, ani dla samej instytucji PRD, ani dla szczegółowych rozwiązań dotyczących jej funkcjonowania. Nie taki jest bowiem cel regulacji prawnych. Tym niemniej należy pamiętać, że cały Kodeks Prawa Kanonicznego z 1983 r. był wielkim wysiłkiem przeniesienia na język kanonistyczny nauki Soboru Watykańskiego II, a zwłaszcza jego doktryny eklezjologicznej ${ }^{4}$. Jest zatem rzeczą konieczną widzieć w dyspozycji kan. 536, a w konsekwencji także w szczegółowych postanowieniach prawa diecezjalnego, konkretny obraz i wizję Kościoła przedstawioną przez ostatni Sobór. Jego doktryna eklezjologiczna stoi u podstaw owocnej współpracy miedzy duchownymi i świeckimi w ramach struktur przewidzianych przez prawo kościelne.

W konstytucji promulgującej nowy Kodeks Prawa Kanonicznego Jan Paweł II wskazał, że do zasadniczych elementów soborowej eklezjologii należą m.in.: doktryna, w której Kościól jest przedstawiany jako Lud Boży (KK 2), a władza hierarchiczna jako stużba (KK 3), [...] doktryna, która ukazuje Kościót jako Wspólnote [...]; doktryna, wedtug której wszyscy czlonkowie Ludu Bożego, w sposób sobie właściwy, partycypuja $w$ potrójnym zadaniu Chrystusa, mianowicie kaptańskim, królewskim i prorockim, do której to doktryny dochodzi także wszystko, co dotyczy obowiazków i praw wiernych, a szczególnie osób świeckich ${ }^{5}$.

W papieskiej wypowiedzi zostały wyróżnione dwa pojęcia Kościoła: Lud Boży i Wspólnota. Stanowią one jedne z wielu możliwych opisów nowej społeczności założonej przez Jezusa Chrystusa. W oparciu o każde z nich można przedstawić i objaśnić zasadnicze fundamenty współpracy pomiędzy duchowieństwem a świeckimi $w$ radach duszpasterskich. Zwrócimy uwagę na to drugie

${ }^{4}$ J a n Paweł I I: Konstytucja apostolska Sacrae disciplinae leges. W: KPK. Poznań 1984 s. 13

${ }^{5}$ Tamże s. $13-15$. 
pojęcie $^{6}$, gdyż od lat osiemdziesiątych minionego stulecia dominuje ono w eklezjologii katolickiej ${ }^{7}$.

\section{Komunia z Bogiem}

Za W. Kasprem należy najpierw stwierdzić, że komunijne pojęcie Kościoła nie wyraża na pierwszym miejscu jego struktury, ale wskazuje przede wszystkim na wtaściwa «rzecz», z której Kościót bierze poczatek i dla której żyje. Pojęcie to opisuje i oddaje najpierw misterium osobowej jedności każdego człowieka z Trójca Święta $[\ldots]^{9}$. To jest pierwszy i zarazem podstawowy wymiar communio Kościoła: więź z Bogiem. Stanowi ona Boży dar dla człowieka, jest owocem Bożej inicjatywy, wypełnionej $w$ paschalnych wydarzeniach męki, śmierci i zmartwychwstania Chrystusa ${ }^{10}$. To w Nim komunia człowieka z Bogiem ma swoje jednorazowe historyczne urzeczywistnienie, a zarazem osiąga swój szczyt. Wspólnota Bóstwa i Człowieczeństwa w Chrystusie staje się podstawą dla komunii wierzących z Bogiem. Ten pierwszy wymiar komunii Kościoła sprawia, że kościelnej communio nie można zestawiać z jakakolwiek ludzka wspólnota, organizacja, stowarzyszeniem, czy zgromadzeniem. Nie pozwala na to jej bosko-ludzki charakter. Jej źródtem nie jest konsens, ugoda, lecz ścisłe, osobowe związanie, zjednoczeniem z Jezusem, którego wzorem, źródtem i celem jest jedność Syna z Ojcem w darze Ducha Świętego ${ }^{11}$.

\section{a) Kościót jako misterium osobowej jedności z Trójca Święta}

Komunia z Bogiem jest zjednoczeniem z Tym, który w swej wewnętrznej istocie jest komunią Osób: Ojcem, Synem i Duchem Świętym. On nieustannie obdarowuje ludzi swoją wewnętrzną communio. On też jest modelem Kościoła

\footnotetext{
${ }^{6}$ Jak zauważono już wcześniej, parafialne rady duszpasterskie są dzisiaj dosyć powszechnie przedstawiane jako jedne ze struktur komunijnych Kościoła, stąd też odwołanie się do eklezjologii komunii jako fundamentu współpracy w PRD jest w pełni uzasadnione.

${ }^{7}$ Eklezjologia komunii jest idea centralna i podstawowa $w$ dokumentach Soboru Watykańskiego II: Synod Biskupów. II Nadzwyczajne Zgromadzenie: Kościół kierowany przez Słowo Boże sprawuje tajemnice Chrystusa dla zbawienia świata. 07.12.1985, II C 1. Wrocław 1986 s. 23. Doniosłość koncepcji communio wynika m.in. z tego, że niezwykle trafnie ujmuje ona wielowymiarowość tajemnicy Kościoła przez co stanowi słowo-syntezę dla opisania całej rzeczywistości Kościoła: J. R a tzinge r: Alcuni aspetti della Chiesa intesa come comunione. W: Pontificie Opere Missionarie, La Chiesa mistero di comunione per la missione. Un contributo teologico e pastorale. Roma 1997 s. 60.

${ }^{8}$ W. K a s p e r: Kościót jako wspólnota. Refleksje nad eklezjologiczna idea przewodnią Soboru Watykańskiego II. ComP R. 6: 1986 nr 4 s. 29.

${ }^{9}$ Kongregacja Nauki Wiary: List Communionis notio do Biskupów Kościoła katolickiego o niektórych aspektach Kościoła pojętego jako komunia, 3. W: W trosce o pelnię wiary. Dokumenty Kongregacji Nauki Wiary 1966-1994. Tarnów 1995 s. 391.

${ }^{10}$ Tamże.

${ }^{11}$ A. C z a j a: Podstawowe elementy eklezjologii communio. „Teologia Praktyczna”. T. 3 : 2002 s. 46.
} 
trwającego w jedności, a jednocześnie pełnego wielości i różnorodności. Charakter trynitarny Kościoła sprawia, że możemy w nim widzieć jednocześnie wspólnotę Ludu Bożego, Mistyczne Ciało Chrystusa i Świątynię Ducha Świętego.

Związek z Ojcem uwidacznia pojęcie Kościoła jako Ludu Bożego. Biblijne korzenie tego pojęcia odsłaniają, że oznacza ono przede wszystkim pokrewieństwo z Bogiem, relację do Niego i związek pomiędzy Bogiem i społecznością określaną tym mianem $^{12}$. Lud Boży pochodzi z zamysłu Ojca i pielgrzymuje do Niego. Lud ten nie istnieje dla siebie samego, lecz jest narzędziem Boga stużacym gromadzeniu ludzi i prowadzeniu ich do Niego ${ }^{13}$. Sobór Watykański II nazywa Kościół nowym Ludem Bożym, i opisuje syntetycznie jego nowość w czterech krótkich wyrażeniach: Głową tego Ludu jest Chrystus; udziałem jest wolność i godność dzieci Bożych; prawem jest nowe przykazanie miłości; celem jest Królestwo Boże (KK 9). Pojęcie to nie odnosi się do jednej grupy czy jednego stanu w Kościele, tak by można było utożsamić Lud Boży np. jedynie z wiernymi świeckimi, ale dotyczy ono całego Kościoła ${ }^{14}$. Wszyscy bowiem ochrzczeni tworzą Lud Boży i uczestniczą w potrójnej misji Chrystusa, choć różnią się powołaniami. Bycie ludem nie ma zatem $\mathrm{w}$ sobie nic z przeciwstawiania sobie stanów w Kościele; nie oznacza też żadnej demokracji ludowej, gdyż lud ten jest ludem Boga, który wie skąd wyszedł i dokąd zmierza. Nie da się zrozumieć Kościoła $\mathrm{z}$ pominięciem Boga.

Kościół jest Ludem Bożym jedynie przez żywe odniesienie do Chrystusa. Wewnętrzną więź z Nim przybliża pojęcie Mistycznego Ciała Chrystusa. Pokazuje ono, że Kościół nie jest jedynie jakimś zgromadzenie wierzących wokół Jezusa, ale stanowi rzeczywiste zjednoczenie z Nim (KKK 789). Określenie to uwypukla najpierw jedność Kościoła, której zasadą i źródłem jest Chrystus. Jedność ciała nie eliminuje różnorodności członków ani różnorodności darów i posług, jakie posiadają, jednakże zróżnicowanie to nie może szkodzić jedności, tak samo jak jedność nie może oznaczać zakwestionowania wielości i różnorodności osób i zadań w Kościele ${ }^{15}$. Dla harmonijnego współistnienia w organizmie Kościele potrzebna jest współpraca i współdziałanie wszystkich ${ }^{16}$. Pojęcie Kościoła jako Mistycznego Ciała wskazuje także na jego Głowę, którą jest Chrystusa. To

${ }^{12}$ J. R a t z i n g e r: Eklezjologia konstytucji „Lumen gentium”. W: T e n ż e: Kościót. Pielgrzymująca wspólnota wiary. Kraków 2005 s. 115.

${ }_{13}$ Tamże s. 116.

${ }^{14}$ Dlatego II rozdziału Lumen gentium nie można traktować jako podstawy do teologii laikatu, gdyż do Ludu Bożego należą wszyscy ochrzczeni: J. R a t z i n g e r: Eklezjologia II Soboru Watykańskiego. W: T e n ż e: Opera omnia. T. VIII/1: Kościót - znak wśród narodów. Lublin 2013 s. 250

${ }^{15}$ J a n P a weł I I: Kościót - Ciało Chrystusa, 3. Audiencja generalna, 20.11.1991. W: Wierza w Kościót jeden, święty. powszechny i apostolski. Città del Vaticano 1996 s. 74.

${ }^{16}$ Nie może więc oko powiedzieć ręce: Nie jesteś mi potrzebna, albo głowa nogom: Nie potrzebuje was (1 Kor 12,21). 
Jemu przysługuje zawsze pierwszeństwo nad Kościołem. Zadaniem zaś wierzących jest upodabniać się do Niego, wzrastać ku Niemu (KKK 794) i dążyć, aby On się w nich ukształtował (por. Ga 4,19).

Komunia z Bogiem oznacza także szczególne więzi z Duchem Świętym ${ }^{17}$. Kościół jest Jego świątynią ${ }^{18}$. Zamieszkiwanie Ducha Świętego w Kościele i w sercach wiernych przynosi życiodajne skutki Kościołowi. Uświęca On bowiem nieustanie Kościół, odnawia go, sprawia, że zawsze jest żywy, młody i pełen dynamizmu. Jak w Trójcy Przenajświętszej Duch Święty jest więzią Ojca i Syna, tak w Kościele jest On niewidzialna przyczyna, której należy przypisać utrzymywanie tączności wszystkich części Ciała między soba i z ich wzniosta Gtowa, ponieważ jest On cały w Ciele, caty $w$ Glowie, caty w poszczególnych członkach (KKK 797). Tę jednoczącą rolę Ducha Świętego oddają także słowa soborowego dekretu o ekumenizmie: Duch Święty, który mieszka w wierzących oraz napetnia Kościót i kieruje nim, sprawit owa cudowna komunię wiernych i tak głęboko jednoczy wszystkich $w$ Chrystusie, że jest zasada jedności Kościoła (DE 2). Dlatego też więzy, które łączą wierzących w Kościele nie są więzami krwi i ciała, ale więzami Ducha Świętego, którego otrzymują wszyscy ochrzczeni. On też jest Tym, który buduje Kościół (por. KKK 798) i uposaża go różnymi darami, posługami i charyzmatami, udzielając ich w sposób całkowicie wolny i zawsze dla dobra Kościoła (por. KK 12). Ponieważ dary te udzielane są zarówno duchownym, jak i świeckim i osobom konsekrowanym, dlatego jest czymś oczywistym, że nie należy nigdy przeciwstawiać sobie wymiaru instytucjonalnego i charyzmatycznego Kościoła, gdyż obydwa te wymiary mają to samo źródło. Duch Święty jest także zasadą wszystkich żywotnych i zbawczych działań w Kościele (KKK 798), stąd też wszystkim wiernym powinna towarzyszyć stała gotowość i otwartość na Jego natchnienia i umiejętność indywidualnego i wspólnotowego wsłuchiwania się w to, co mówi Duch do Kościołów (Ap 2-3).

\section{b) Środki urzeczywistniające komunię z Bogiem}

Więź z Bogiem stanowiąca podstawowy wymiar komunii Kościoła urzeczywistnia się i realizuje w słowie Bożym i sakramentach ${ }^{19}$. Mówi o tym m.in. soborowy dekret o apostolstwie świeckich, stwierdzając: [...] życie wewnętrznego zjednoczenia z Chrystusem w Kościele żywi się pomocami duchowymi, które sq wspólne dla wszystkich wiernych, a zwłaszcza czynnym udziałem $w$ świętej liturgii (DA 4). Wśród sakramentów, które objawiają i realizują tajemnicę zjednoczenia człowieka z Trójjedynym Bogiem, szczególne znaczenie odgrywają chrzest i Eucharystia. Chrzest św. daje dostęp do komunii z Bogiem, czyni przy-

\footnotetext{
${ }^{17} \mathrm{~J}$ a n P awe 1 I I stwierdza: Kościelna komunia jest wielkim darem Ducha Świętego: ChL 20.

${ }^{18}$ Czyż nie wiecie, żeście światynia Boga i że Duch Boży mieszka w was? (1 Kor 3,16).

${ }^{19}$ Synod Biskupów, dz. cyt. II, C, 1.
} 
branymi dziećmi Bożymi, włącza w Chrystusa, w Jego zbawcze misteria i Jego misję, obdarza darem Ducha Świętego. Natomiast w Eucharystii komunia z Bogiem znajduje swoje jedyne i wyjątkowe centrum ${ }^{20}$. W sakramencie tym wierzący uczestniczą w sposób rzeczywisty w Ciele Pańskim, wznoszą się do komunii z Nim i nawzajem ze sobą (KK 7). Wspólne uczestnictwo w Sakramencie Miłości i przyjmowanie Chrystusa eucharystycznego musi się przekładać na styl życia i działania wspólnoty chrześcijańskiej. Domaga się przezwyciężenia podziałów i wzywa, aby stanowić jedno ciało w Chrystusie.

Komunia z Bogiem realizuje się również poprzez słowo Boże, albowiem Bóg, który niegdyś przemówit, bezustannie rozmawia z Oblubienica swego umitowanego Syna, a Duch Święty, dzięki któremu żywy gtos Ewangelii rozbrzmiewa w Kościele, a przez Kościót w świecie, doprowadza wierzacych do calej prawdy $i$ sprawia, że słowo Boże przebywa w nich obficie (KO 8). Słowo Boże jednoczy z Bogiem, albowiem każdy kto $\mathrm{z}$ wiarą je czyta, słucha, medytuje, wchodzi w relację z Tym, od którego to słowo pochodzi. Jest ono zawsze życiodajnym źródłem, z którego Kościół czerpie, i przez które wzrasta jego komunia.

Wymiar wertykalny pokazuje, że communio nie realizuje się »od dotu«. Jest ona łaska i darem, wspólnym uczestnictwem $w$ jednej prawdzie, $w$ jednym życiu $i$ jednej miłości, której udziela nam Bóg przez Jezusa w Duchu Świętym, a która staje się naszym udziatem przez stowo i sakramenty ${ }^{21}$.

\section{Komunia między wierzącymi}

Zjednoczenie z Bogiem w Trójcy Jedynym, realizujące się i doświadczane w słowie Bożym i sakramentach, stanowi fundament Kościoła rozumianego jako komunia. Ono też prowadzi do komunii wierzących miedzy sobą. W wymiarze horyzontalnym Kościół ukazuje się m.in. jako komunia wiernych i komunia hierarchiczna $^{22}$. Obydwa te aspekty mają wielkie znaczenie dla kwestii wspólpracy duchownych i świeckich $\mathrm{w}$ ramach $\mathrm{PRD}$, i żadnego $\mathrm{z}$ nich nie można pominąć ani pomniejszyć.

\section{a) Komunia wiernych}

Communio fidelium wyraża podstawową formę struktury Kościoła ${ }^{23}$. Tworzą ją wszyscy wierni od momentu przyjęcia chrztu świętego (KPK, kan. 204 § 1). Na bazie tego sakramentu Kościół stanowi jedność; jest wspólnotą braterską, wspólnotę ochrzczonych, obdarzonych tą samą godnością. Chrzest jest podstawą

\footnotetext{
${ }^{20}$ Kto spożywa Ciało moje i Krew moja pije, trwa we Mnie, a Ja w nim (J 6,56).

${ }^{21}$ W. K a s p e r, art. cyt., s. 34.

${ }^{22}$ Trzecim aspektem communio Kościoła w wymiarze horyzontalnym jest to, że stanowi on wspólnotę Kościołów partykularnych. Ten aspekt nie będzie tutaj przybliżany.

${ }^{23}$ W. K a s p e r, art. cyt., s. 39.
} 
równości ${ }^{24}$ i autentycznego braterstwa w Kościele, które sprawia, że nie ma w nim podziału na członków lepszych i gorszych. Stwierdza to wyraźnie Sobór Watykański II: [...] co się tyczy godności i wspólnej wszystkim wiernym działalności około budowania Ciała Chrystusowego, prawdziwa równość panuje wśród wszystkich (KK 32). Charakter chrzcielny sprawia, że wszyscy christifideles uczestniczą, we właściwy każdemu sposób, w kapłańskiej, prorockiej i królewskiej misji Chrystusa.

Dopiero wychodząc od tej podstawowej charakterystyki Ludu Bożego, należy wskazać na istniejącą w nim wielość i zróżnicowanie. Kościół jest bowiem uformowany jako komunia organiczna, która charakteryzuje się zróżnicowaniem a zarazem komplementarnością powołań i stanów, posług i charyzmatów. Ilustruje to dobrze fragment konstytucji Lumen gentium, w której Ojcowie soborowi stwierdzają: Rozróżnienie, które Pan uczynił między wyświęconymi szafarzami a reszta ludu Bożego, niesie z soba taczność , gdyż pasterze i inni wierni zwiazani sa mocno ze soba ścista więziq. Pasterze Kościoła, idąc za przykladem Pana, oddaja postugi duchowe sobie nawzajem i innym wiernym, ci zaś ochoczo świadcza wspólnie pomoc pasterzom i nauczycielom. Tak wszyscy w rozmaitości daja świadectwo o przedziwnej jedności w Ciele Chrystusa (KK 32) ${ }^{25}$. Zróżnicowanie istniejące w Kościele jest jego bogactwem; sprawia ono, że Kościół może lepiej wzrastać i skuteczniej pełnić powierzoną mu misję bycia sola ziemi i świattem świata (Mt 5,13-14).

Communio fidelium uwypukla jeszcze jeden element. Jest nim aktywne uczestnictwo całego ludu Bożego w życiu Kościoła. Synod Biskupów z 1985 r. wyraził to w sposób jednoznaczny: Ponieważ Kościót jest komunia na wszystkich jego szczeblach powinno mieć miejsce uczestnictwo $i$ współodpowiedzialność ${ }^{26}$. Oznacza to, że nie może być w Kościele podziału na aktywnych i pasywnych ${ }^{27}$. Wskazał na to dobitnie Sobór Watykański II, ucząc, że ten, kto nie działa wedtug swej miary dla wzrostu ciała, nie jest pożyteczny ani dla Kościoła, ani dla siebie (DA 2). Wszyscy członkowie Kościoła są wezwani do uczestnictwa i współodpowiedzialnej współpracy $\mathrm{w}$ budowaniu Kościoła i zbawianiu świata ${ }^{28}$.

${ }^{24} \mathrm{~J}$. R a t z i n g e r zwraca jednak uwagę, że równości tej nie należy traktować w sposób egalitarystyczny, zgodnie z którym w communio mogą istnieć tylko całkowicie sobie równi: T e n ż e: Eklezjologia konstytucji „Lumen gentium”, art. cyt., s. 119.

${ }^{25} \mathrm{~W}$ organicznej komunii Kościoła każdy przyczynia się do rozwoju całości, jeśli żyje zgodnie $\mathrm{z}$ własnym powołaniem.

${ }^{26}$ Synod Biskupów, dz. cyt. II, C, 6.

${ }^{27}$ W. K a s p er, art. cyt., s. 39.

${ }^{28} \mathrm{~W}$ takiej perspektywie świeckich nie można uważać jedynie za «wspótpracowników» duchowieństwa, ale za osoby rzeczywiście «współodpowiedzialne» za bycie $i$ działanie Kościoła: B e nedykt X V I: Przestanie na VI Zgromadzenie Ogólne Międzynarodowego Forum Akcji Katolickiej, Jassy, 22-26.08.2012. Cyt. za http://www.opoka.org.pl/aktualnosci/news.php? id= 44077\&s=opoka [dostęp: 30.07.2013]. 
Realizacji tych zasad dokonuje się także za pośrednictwem konkretnych struktur kościelnych. Jedną z nich jest PRD. Jej istnienie i właściwe funkcjonowanie sprawia, że komunia wiernych znajduje swój konkretny wyraz we wspólnocie parafialnej.

\section{b) Komunia hierarchiczna}

Ten aspekt communio podkreśla istotną rolę posługi pasterz y Kościoła, a zwłaszcza episkopatu. W osobach biskupów, a także w osobach ich pomocników - prezbiterów - jest zawsze obecny wśród swoich wiernych Jezus Chrystus. To On obdarza pasterzy Kościoła szczególnym darem Ducha Świętego, który nie tylko daje im udział w potrójnej misji Zbawiciela, lecz uzdalnia ich do reprezentowania Chrystusa, Głowy i Pasterza Kościoła ${ }^{29}$. Tworzą oni komunię hierarchiczną $^{30}$, która stanowi konieczny warunek istnienia Kościoła. Watykańska instrukcja Ecclesiae de mysterio podkreśla, że kapłaństwo sakramentalne jest niezbędnym warunkiem samego istnienia wspólnoty jako Kościoła. [...] Jeśli we wspólnocie zabraknie kapłana, zostaje ona pozbawiona sakramentalnej praktyki i funkcji Chrystusa Głowy i Pasterza, która ma kluczowe znaczenie dla życia samej wspólnoty kościelnej ${ }^{31}$.

Dzięki posłudze papieża, biskupów i prezbiterów, Kościół będąc obdarzony bogactwem i różnorodnością powołań, stanów i funkcji, zachowuje jedność życia i celu działania. Jasno ukazał to ostatni Sobór stwierdzając: Celem pasterzowania ludowi Bożemu i jego nieustannego pomnażania Chrystus Pan ustanowit w swoim Kościele rozmaite postugi, które nakierowane sa na dobro całego Ciała. Wyposażeni bowiem $w$ święta władzę szafarze stuża swoim braciom, aby wszyscy, którzy należa do Ludu Bożego i dlatego ciesza się prawdziwie chrześcijańska godnościa, w sposób wolny $i$ uporządkowany dąża do tego samego celu, doszli do zbawienia (KK 18).

Posługa pasterzy Kościoła realizuje się przez służbę na rzecz dobra całego Mistycznego Ciała Chrystusa. Do tej służby są oni uzdolnieni i zobowiązani. Zostali bowiem wybrani i szczególnie obdarowani, nie dla wynoszenia się nad innych, lecz aby służyć Chrystusowi i wspólnocie Kościoła ${ }^{32}$. Ich autorytatywne

\footnotetext{
${ }^{29}$ A. C z a j a, art. cyt., s. 56.

${ }^{30}$ Teksy Soboru Watykańskiego odnoszą komunię hierarchiczną do relacji biskupów z papieżem w Kościele powszechnym oraz biskupów z prezbiterami w Kościele partykularnym.

${ }^{31}$ Kongregacja ds. Duchowieństwa i Inne: Instrukcja »Ecclesiae de mysterio« o niektórych kwestiach dotyczacych wspótpracy wiernych świeckich $w$ ministerialnej postudze kaptanów. „L'Osservatore Romano”. Wydanie polskie. R. 19: 1998 nr 12 pkt 3 s. 33.

${ }^{32} \mathrm{~W}$. K a s p e r zauważał w połowie lat osiemdziesiatych, że w sytuacji, gdy jawnie utyka wielka idea communio fidelium, to ,pierwszoplanowym zadaniem kościelnego urzędu i jego służby na rzecz jedności jest przywrócenie dialogu i komunikacji, wnosząc przy tym w proces wewnątrzkościelnej komunikacji obowiązującą naukę Kościoła (...), aby w ten sposób odbudować pełną i niepodzielną communio i communicatio fidelium. Ideałem tej communio nie jest brak napięć.
} 
głoszenie słowa Bożego, sprawowanie sakramentów i pasterskie przewodzenie wiernym musi się dokonywać zawsze w duchu służby i w kolegialnej wspólnocie z papieżem, biskupami i prezbiterami ${ }^{33}$.

Wraz z tym aspektem zamyka się całość rozumienia Kościoła. Przywołane aspekty wymiaru horyzontalnego, wraz z nieomawianą tutaj communio Ecclesiarum, nie występują jeden obok drugiego, ale się wzajemnie przeplatają i przenikają, i razem z wymiarem wertykalnym, od którego nie mogą być odłączone, tworzą to, co Sobór nazwał Misterium Kościoła (KK rozdział 1$)^{34}$.

\section{Duchowość komunii}

Kościół w swojej działalności pastoralnej niesie pomoc ludziom, aby mogli przyjąć dar komunii z Bogiem, i przez nią budować komunię wzajemną. Innymi słowy, Kościół pragnie stawać się domem komunii, czyli wspólnotą, miejscem i przestrzenią, w której wierzący mogą doświadczać spotkania z Bogiem, realizować wzajemne braterstwo pod służebnym przewodnictwem pasterzy, i tak zjednoczeni podążać wspólnie do pełni eschatologicznej komunii z Bogiem. Choć w całym Kościele i w poszczególnych wspólnotach wierzących podejmowane są nieustannie różne działania, inicjatywy i przedsięwzięcia pastoralne, to ostatecznie powinny się one zawsze wpisywać $\mathrm{w}$ to podstawowe zadanie wynikające $\mathrm{z}$ samej natury Kościoła.

Dążenie do budowania Kościoła jako domu komunii łączy się harmonijnie z wysiłkami formacyjnymi, mającymi na celu uczenie i przyswajanie przez wiernych, tego co Jan Paweł II nazwał w Novo millennio ineunte, duchowościa komunii (NMI 43). Stanowi ona zasade wychowawcza, podejmowaną we wszystkich środowiskach formacyjnych, w których wzrastają wierzący. Krzewienie i rozwijanie duchowości komunii jest zadaniem, z którego nikt nie może czuć się zwolniony. Zarówno formacja do kapłaństwa, jak i do życia konsekrowanego, a także do bycia wiernym świeckim, winna mieć w swoim centrum kształtowanie takiej duchowości. Nabycie jej pozwala podejmować, w sposób odpowiedzialny i we współpracy z innymi, realizację własnego powołania. Także w odniesieniu do doskonalenia współpracy miedzy duchownymi a świeckimi w ramach rad dusz-

Wszelkie życie dokonuje się, jak wykazał J. A. M ö h l e r, w napięciach. Gdzie zamierają napięcia, tam panuje śmierć. Tymczasem my chcemy nie Kościoła martwego, ale żywego! Jednakże należy odróżnić między prawdziwymi napięciami, których bieguny są wobec siebie komplementarne, a sprzecznościami bez związku, a nawet nieprzezwyciężalnymi, które się wzajemnie izolują i pod względem postaw i logiki - wykluczają. Ale w communio Kościoła, jak znowu wykazał M ö h 1 e r, nie może jeden, ani wszyscy, być wszystkim. »Wszystkim mogą być tylko wszyscy, a jedność wszystkich tylko całością. Taka jest idea Kościoła katolickiego «": art. cyt., s. 40-41.

${ }^{33}$ A. $\mathrm{C} \mathrm{z}$ a j a, art. cyt., s. 57.

${ }^{34} \mathrm{H} . \mathrm{M}$ ü hl $\mathrm{e}$ r: Communione eccesiale e strutture di corresponsabilità: dal Vaticano II al Codice di diritto canonico. W: Communione eccesiale e strutture di corresponsabilità. Red. J. B e y e r, G. Fe li c i an i, H. M üh ler. Roma 1990 s. 25-26. 
pasterskich, duchowość komunii jawi się jako warunek sine qua non dla wszystkich tworzących tę strukturę komunijną Kościoła.

We wspomnianym wyżej Liście apostolskim Jan Paweł II nakreślił istotne elementy duchowości komunii, które w odniesieniu do analizowanej problematyki zasługują na dosłowne przytoczenie: Duchowość komunii to przede wszystkim spojrzenie utkwione $w$ tajemnicy Trójcy Świętej, która zamieszkuje w nas $i$ której blask należy dostrzegać także w obliczach braci żyjacych wokót nas. Duchowość komunii to także zdolność odczuwania więzi z bratem $w$ wierze dzięki głębokiej jedności mistycznego Ciała, a zatem postrzegania go jako «kogoś bliskiego», co pozwala dzielić jego radości i cierpienia, odgadywać jego pragnienia i zaspokajać jego potrzeby, ofiarować mu prawdziwa i glęboka przyjaźń. Duchowość komunii to także zdolność dostrzegania $w$ drugim człowieku przede wszystkim tego, co jest w nim pozytywne, a co należy przyjać i cenić jako dar Boży: dar nie tylko dla brata, który bezpośrednio go otrzymat, ale także «dar dla mnie». Duchowość komunii to wreszcie umiejętność «czynienia miejsca» bratu, wzajemnego «noszenia brzemion» (por. Ga 6, 2) i odrzucania pokus egoizmu, które nieustannie nam zagrażaja, rodzac rywalizację, bezwzględne dążenie do kariery, nieufność, zazdrość. Nie tudźmy się: bez takiej postawy duchowej na niewiele zdatyby się zewnętrzne narzędzia komunii. Statyby się bezdusznymi mechanizmami, raczej pozorami komunii niż sposobami jej wyrażania i rozwijania (NMI 43).

Do tej wypowiedzi można jeszcze dołączyć, jako podsumowanie tej części, słowa Benedykta XVI skierowane do członków Prezydium Komitetu Centralnego Katolików Niemieckich: Kościót w Niemczech jest doskonale zorganizowany. Czy jednak za tymi strukturami jest odpowiadajaca im siła duchowa - siła wiary w Boga żywego? Uczciwie trzeba powiedzieć jak sadze - ze istnieje u nas przerost struktur nad duchem. Chciałbym dodać, że prawdziwym kryzysem Kościoła $w$ świecie zachodnim jest kryzys wiary. Jeśli nie odnajdziemy prawdziwej odnowy wiary, wszystkie reformy strukturalne będq nieskuteczne ${ }^{35}$.

\section{Niektóre problemy i trudności we wzajemnej współpracy}

Eklezjologia komunii stosowana $\mathrm{w}$ praktyce zarówno przez duchownych i świeckich pozwala przezwyciężyć większość trudności w ich wzajemnej współpracy na forum PRD. Wynikają one bowiem w znacznym stopniu m.in. z jedynie horyzontalnego postrzegania Kościoła, z błędnego pojmowania instytucji rad w Kościele, z nierozumienia roli własnej i roli innych w tego typu

\footnotetext{
${ }^{35}$ B e n e d y k t X V I: Szukajmy nowych dróg ewangelizacji. Spotkanie z członkami Prezydium Centralnego Komitetu Katolików Niemieckich. Fryburg. 24.09.2011. „L’Osservatore Romano". Wydanie polskie. R. 32: 2011 nr 12 s. 33.
} 
strukturze, ze słabego zaangażowania, z braku zaufania czy nieumiejętności dialogu. Kierowanie się w praktycznym działaniu duchowością komunii jest skutecznym antidotum na liczne niedostatki $\mathrm{w}$ funkcjonowaniu tej struktury komunijnej.

W niniejszym punkcie zostanie zwrócona uwaga na nieco inne trudności. Pierwsza z nich dotyczyć będzie samej natury rady i wynikających z niej zadań. Druga odnosi się do trudności napotykanych w rozumieniu i praktykowaniu głosu doradczego; trzecia zaś dotyka kwestii przebiegu spotkań rady.

\section{Jakie zadania ma PRD?}

II Polski Synod Plenarny (1991-1999) w dokumencie poświęconym powołaniu i posłannictwu świeckich stwierdził: Niepokojacym zjawiskiem jest brak odpowiednio szerokiej wspótpracy kaptanów ze świeckimi w planowaniu przedsięwzięć duszpasterskich i materialnych w parafii. Świeccy często nie zdaja sobie sprawy z możliwości takiej wspótpracy pod przewodnictwem proboszcza. W praktyce $w$ wielu parafiach nie istnieja lub nie wypetniaja swych zadań rady duszpasterskie i ekonomiczne ${ }^{36}$. Diagnoza ta, choć postawiona kilkanaście lat temu, wydaje się ciągle aktualna. Pomijając w tym miejscu sprawę nieobecności PRD w życiu wielu wspólnot parafialnych, należy się zastanowić nad wskazanym przez Synod brakiem wypełniania przez radę duszpasterską właściwych jej zadań.

Najpierw należy zauważyć, że wielu parafiach rady duszpasterskie są de facto radami ekonomicznymi, gdyż zajmują się $\mathrm{w}$ większości jedynie sprawami materialnymi ${ }^{37}$. Jest wiele przyczyn takiego stanu rzeczy. Jedna $\mathrm{z}$ nich uwidacznia się w sytuacji, gdy biskup diecezjalny wydaje dekret o konieczności powołania rad duszpasterskich, i pozostawia proboszczom dobór członków rady, wówczas dochodzi często do prostego przekształcania istniejących już w parafiach zespołów ludzi wspierających proboszcza w sprawach gospodarczych w PRD, która zajmuje się w tymi samymi sprawami co poprzednio. Inna przyczyna tkwi w prostym fakcie, że sprawami ekonomicznymi łatwiej się zajmować. Choć współpraca między proboszczem a członkami rady może i w takim obszarze napotykać na pewne trudności, to jednak zasadniczo dyskusja, dialog i podejmowanie konkretnych rozwiązań dla spraw materialnych w parafii dokonują się łatwiej i przy wzajemnym zrozumieniu i współdziałaniu. Jeszcze innym powo-

${ }^{36}$ II Polski Synod Plenarny (1991-1999): Sól ziemi. Powołanie i posłannictwo świeckich, 29. Poznań 2001 s. 152.

${ }^{37}$ Nie dotyczy to tych diecezji, w których na mocy rozporządzenia biskupa diecezjalnego, parafialna rada duszpasterska i parafialna rada ds. ekonomicznych zostały złączone w jedną strukturę jako rada parafialna, która spełnia funkcje obu wymienionych rad. Por. m.in. Statut rady parafialnej $w$ diecezji legnickiej, I.2. W: I Synod Diecezji Legnickiej 2007-2012. T. 1: Program odnowy religijno-moralnej. Legnica 2012 s.146. 
dem chętniejszego zajmowania się sprawami ekonomicznymi niż duszpasterskimi jest przekonanie, występujące zarówno u kapłanów jak i wiernych świeckich, że obszar spraw duszpasterskich winien pozostawać wyłącznie w gestii duchownych. Wszystko to sprawia, że PRD są za mało duszpasterskie.

Tymczasem ich charakter jest jednoznaczny: są one strukturami, których członkowie powołani są, aby nieść pomoc ad actionem pastoralem ${ }^{38}$. Współpraca w sprawach duszpasterskich niejednokrotnie okazuje się bardziej wymagająca niż wspólne działania na polu ekonomicznym. Widzą te trudności zarówno proboszczowie, którzy doświadczają nieumiejętności działania świeckich w obszarze duszpasterskim i ich słabego przygotowania teologicznego. Podobnie i świeccy spotykają się u duchownych z postawami marginalizującymi ich udział w organizacji działalności pastoralnej, spychającymi ich jedynie do roli wykonawców niektórych zewnętrznych działań materialnych towarzyszących inicjatywom duszpasterskim ${ }^{39}$. Zdarzają się sytuacje, że w nowo powołanych radach, znajdują się osoby pełne zapału, które poznawszy zakres działań PRD ujęty w Statucie, pragną zaangażować się w ich realizację. Szybko się jednak przekonują, że w istocie zadania te nie są podejmowane na spotkaniach rady, a jeśli już, to doświadczają, że ich rola powinna się ograniczyć do prostego zaakceptowania planów i wizji proboszcza ${ }^{40}$. Prowadzi to w konsekwencji do bierności i stopniowego wycofywania się z zaangażowania w PRD.

Poprawa tej sytuacji zależy nie tyle od prawodawcy kościelnego, co od samych duchownych i świeckich tworzących radę. Rzeczywistość Kościoła w Polsce każe tutaj jednak dopowiedzieć, że osobą, która ma większy wpływ na rzeczywiste podjecie duszpasterskich zadań przez PRD, jest proboszcz. Im bardziej włącza on członków rady w te zadania, o których mówią dokumenty Kościoła, tym większa szansa na ich rzeczywiste zaangażowanie. Rady są bowiem także szkołą formacji i lepszego poznania przez świeckich form i sposobów pełnienia przez Kościół jego misji ${ }^{41}$.

${ }^{38} \mathrm{KPK}, \mathrm{kan} .536 \S 1$.

39 Tak postrzegane zaangażowanie na polu duszpasterskim przejawia się m.in. w tym, że świeckim członkom rady powierza się tylko takie działania jak np. przygotowanie ołtarza na uroczystość Bożego Ciała.

${ }^{40} \mathrm{~W}$ wielu wypowiedziach świeckich pojawiają się spostrzeżenia, że rola członków PRD sprowadza się do przytakiwania inicjatywom proboszcza: zob. m.in. komentarze na forum internetowym po wydaniu w 2011 r. Statutu PRD w diecezji warszawsko-praskiej: http://www.diecezja. waw.pl/dokument.php?id=2168 [dostęp: 30.03.2013 r.].

${ }^{41} \mathrm{E} . \mathrm{M}$ i r a g o 1 i: Il Consiglio pastorale parrocchiale: fra teoria e prassi. W: Partecipazione e corresponsabilità nella Chiesa. I consigli diocesani e parrocchiali. Red. M. R i v e 11 a. Milano 2000 s. 263-264. 


\section{Trudności z glosem doradczym}

Problematyka głosu doradczego przyznanego PRD przez normę prawa powszechnego (kan. 536 § 2) stanowi jedną z najważniejszych trudności we współpracy miedzy duchownymi i świeckimi. Trudność ta jest postrzegana przede wszystkim przez członków rady, z których większość stanowią świeccy. To przede wszystkim im towarzyszy świadomość, że posiadanie jedynie głosu doradczego wydaje się stać w sprzeczności z zasadami uczestnictwa i współodpowiedzialności. Doradczość, a nie decyzyjność, sprawia, że w przypadku, kiedy proboszcz podejmie inną decyzję niż owa „rada” dana mu przez radę duszpasterską, to jej członkowie czują, że ich głos jest pozbawiony znaczenia; odbierają to często jako nieliczenie się z ich zdaniem, pozbawianie ich wpływu na podejmowaną decyzję, kwestionowanie ich odpowiedzialności, kiedy indziej zaś jako autorytaryzm proboszcza i podejmowanie arbitralnych decyzji.

Przyczyny takiego pojmowania znaczenia głosu doradczego, jak i kompetencji samej rady, są zasadniczo dwojakiego rodzaju. Pierwszą i chyba najważniejszą przyczyną trudności w zrozumieniu i akceptacji głosu doradczego PRD jest niewłaściwe pojmowanie samego Kościoła. Jeśli postrzega się go tylko przez pryzmat równości wszystkich, która pochodzi z sakramentu chrztu, a nie dostrzega się w nim różnorodności powołań, zadań, funkcji i posług, dla których fundamentem są także i inne sakramenty, a wśród nich sakrament święceń, wnoszący w Kościół principium hierarchiczne, wówczas głos doradczy jawi się rzeczywiście jako ograniczenie czy niedowartościowanie wiernych świeckich. Łączy się z tym myślenie o kompetencji rady w kategoriach posiadania władzy. Uważa się, że ten kto decyduje, ma większe znaczenie, ci zaś, którzy tylko doradzają, czują się pozbawieni władzy i postawieni przez to na niższym poziomie.

Drugą przyczyną, wynikającą zresztą w jakiś sposób z pierwszej, jest niezrozumienie, czym jest głos doradczy w Kościele, jaka jest jego doniosłość i znaczenie. Uważa się często, że wszelkiego rodzaju „dawanie rad” jest tak oddalone od decydowania, jak oddalone od siebie są dwa bieguny. Innymi słowy zdaniem niektórych (wielu?) - struktura doradcza jaką jest PRD nie ma większego wpływu na podejmowane decyzje, a nawet jest tego wpływu całkowicie pozbawiona. Obydwie przyczyny prowadzą do braku zaangażowania członków rady, a nawet rezygnacji z uczestnictwa.

\section{Prowizoryczność w pracach PRD}

Miejscem współpracy miedzy duchownymi i świeckimi w ramach PRD są zasadniczo spotkania tego zespołu. Niejednokrotnie już sama ich liczba w ciągu roku oraz czas trwania poszczególnych posiedzeń są świadectwem rozumienia roli tej struktury. Sporadyczność spotkań rady, zwoływanej tylko w razie jakiejś konieczności lub użyteczności, nie może pozytywnie wpływać na postrzeganie wzajemnej współpracy. Niesie to ze sobą komunikat, że rada jest instytucja fasa- 
dową, ozdobnikiem, a nie rzeczywistą strukturą komunijną podejmującą troskę o całość spraw duszpasterskich w parafii. Także i sam przebieg spotkań i ich organizacja pokazują jakie znaczenie przyznaje się PRD. Ma to oczywisty wpływ na jakość współdziałania. Oczywiście, element organizacyjny nie powinien być decydujący; nie można wszystkiego uporządkować poprzez odpowiednie postanowienia, zapisy i uregulowania, których należy potem skrupulatnie przestrzegać. Działalność PRD nie powinna być zbytnio sformalizowana, ale nie może też dominować w niej prowizoryczność i brak konsekwencji w działaniu.

Po tych ogólnych uwagach, należy najpierw wskazać na występujący w wielu radach duszpasterskich brak planu pracy i przygotowania spotkań. Członkowie rady najczęściej na początku spotkania dowiadują się czemu będzie ono poświęcone. $\mathrm{Z}$ pewnością nie ułatwia to dyskusji i poszukiwania najlepszych rozwiązań.

Inną kwestią jest brak przejrzystych wniosków i postulatów działania z zagadnień, które były przedmiotem refleksji podczas posiedzenia PRD. Rada nie jest jedynie organizmem studyjnym, który zajmuje się tylko analizą sytuacji, zjawisk i występujących problemów. Nie można poprzestać na diagnozie sytuacji i poznaniu jej przyczyn. Owocem refleksji PRD powinny być konkretne wnioski, które otworzą drogę do działania. To prawda, że czasem dosyć długo dochodzi się do wypracowania najlepszych rozwiązań, ale zasadniczo w większości poruszanych spraw możliwe jest dojście do konkretnych ustaleń. Członkowie rady biorą udział w tym procesie poprzez głos doradczy, ale jest rzeczą ważną, aby poznali podjętą decyzję i jej uzasadnienie. $Z$ zagadnieniem tym łączy się także występujący nieraz brak konsekwencji, polegający na tym, że podjęte decyzje nie są potem wprowadzane w życie.

Rady duszpasterskie rzadko kiedy podejmują na swoich spotkaniach sprawę weryfikacji przeprowadzonych przedsięwzięć duszpasterskich, zarówno tych, które są cyklicznie powtarzane, jak i nowych inicjatyw, które zostały podjęte w odpowiedzi na nowe wyzwania. Działalność pastoralna Kościoła dokonuje się zawsze w konkretnym czasie i miejscu, te zaś okoliczności historyczne podlegają nieustannym zmianom, dlatego weryfikacja prowadzonych działań jest koniecznością. Krytyczna refleksja pozwala eliminować braki i niedostatki w nich występujące, co przyczynia się do ich większej skuteczności.

Rozwojowi i właściwemu kształtowi współpracy w ramach PRD nie służy też takie interpretowanie odpowiedzialności proboszcza za przebieg całego posiedzenia zespołu ${ }^{42}$, które wyłącza członków rady z różnych etapów przygotowania spotkań, ich przebiegu, oraz realizacji podjętych decyzji. Choć wypełnianie niektórych funkcji wewnątrz rady pozostawione jest osobom, które je peł-

\footnotetext{
${ }^{42}$ Według większości uregulowań diecezjalnych to właśnie proboszcz odpowiada za przebieg spotkań PRD.
} 
nią ${ }^{43}$, to jednak generalnie, właśnie proboszczowie kierują i osobiście prowadzą wiele szczegółowych spraw, co powoduje u innych, przywoływaną już wiele razy, postawę bierności.

\section{Możliwe sposoby rozwiązywania trudności i doskonalenia wspólpracy}

Wskazane powyżej przykładowe trudności domagają się zwrócenia uwagi, w jaki sposób można je przezwyciężać, a zarazem polepszać jakość wzajemnej współpracy i przyczynić się w ten sposób do większej efektywności pracy PRD, jak również większego zaangażowania członków rady.

\section{Podejmowanie konkretnych zadań pastoralnych}

Analizując pojawiające się niekiedy wypowiedzi członków PRD na temat poczynań duszpasterskich zauważa się, że najczęściej zajmują się one dość typowymi przejawami życia parafialnego. Jak zauważa K. Jankowiak w artykule Pytania o rady, wśród podejmowanych na spotkaniach PRD zagadnień znajdują się zwykle: organizacja odpustów, rekolekcji, festynów i wydarzeń diecezjalnych w parafiii ${ }^{44}$. Do tego należy jeszcze dodać - opierając się na wynikach badań ankietowych przeprowadzonych $w$ archidiecezji krakowskiej - następujące przedsięwzięcia: akcje charytatywne, zaangażowanie w rozwój życia liturgicznego w parafii i działalność kulturalno-oświatową ${ }^{45}$.

Zauważa się natomiast, czy to $\mathrm{w}$ wypowiedziach samych radnych, jak też innych osób ze wspólnot parafialnych, niedostatek działań związanych z ewangelizacją osób, które oddaliły się od Kościoła, z budowaniem parafii jako prawdziwej wspólnoty, koordynacją grup działających w parafii, duszpasterstwem osób żyjących w związkach pozasakramentalnych, pogłębieniem formacji wiernych ${ }^{46}$.

Kiedy spojrzymy na sformułowanie zadań zawarte w dokumencie Wytyczne w sprawie parafialnych rad duszpasterskich przyjętym przez Konferencję Episkopatu Polski 18 listopada 1975 r. oraz na diecezjalne uregulowania prawne dla tej struktury, to pokazuje się, że są one wytyczone i skierowane ku ważnym,

${ }^{43}$ Przykładem takiej funkcji jest sekretarz PRD.

${ }^{44}$ K. J a n k o w i a k: Pytania o rady. W: Komisja Duszpasterstwa Konferencji Episkopatu Polski: Kościót naszym domem, dz. cyt., s. 241.

${ }^{45}$ Duszpasterskie rady parafialne: ich rola i miejsce w Kościele; materiały z projektu badawczo-szkoleniowego: Kraków 1996-1997. Red. A. P o r ę b s k i. Kraków 1998 s. 58. Ankieta była skierowana do parafii, które posiadały funkcjonujące rady, zaś reprezentatywną grupą osób ankietowanych byli proboszczowi, członkowie PRD oraz inni parafianie.

${ }^{46}$ K. J a n k o w i a k, art. cyt., s. 238-241; J. S z k o d o ń: Potrzeby aktualne Kościoła w Polsce i duszpasterskie rady parafialne $w$ tym świetle. W: Duszpasterskie rady parafialne: ich rola i miejsce w Kościele, dz. cyt., s. 16. 
odpowiedzialnym i angażującym obszarom działań duszpasterskich ${ }^{47}$. Warto przywołać niektóre $\mathrm{z}$ tych zadań: współodpowiedzialne wspieranie kapłanów w organizacji życia duszpasterskiego wspólnoty ${ }^{48}$; współpraca $\mathrm{z}$ proboszczem w poszukiwaniu lepszych form duszpasterskich, dostosowanych do zmieniających się warunków życia i nowych potrzeb, zwłaszcza w liturgii, w katechizacji, w głoszeniu Ewangelii, w dziedzinie charytatywnej ${ }^{49}$; wyrażanie opinii w sprawach parafii oraz wysuwanie propozycji i wniosków dotyczących udoskonalania pracy parafialnej ${ }^{50}$; koordynacja różnych poczynań apostolskich i animowanie działalności grup duszpasterstwa specjalistycznego ${ }^{51}$; troska o pogłębienie religijnej świadomości parafian i budzenie odpowiedzialności za parafię jako wspólnotę $^{52}$; podejmowanie starań, aby dotrzeć do parafian stojących z dala od Kościo$\mathrm{ka}^{53}$; udział $\mathrm{w}$ opracowywaniu rocznego parafialnego planu duszpasterskich w oparciu o program ogólnopolski i diecezjalny ${ }^{54}$.

Bez szczegółowego analizowania poszczególnych zadań i wpływu jaki wywierają na wzajemną współpracę miedzy duchownymi i świeckim, warto zwrócić baczniejszą uwagę na ostatnie z wymienionych przedsięwzięć. Poprzez opracowywaniu rocznego parafialnego planu duszpasterskich PRD wnosi istotny wkład $\mathrm{w}$ organizację duszpasterstwa parafialnego ${ }^{55}$. Plan duszpasterski zbiera $\mathrm{w}$ jedną

47 Są też uregulowania, które bardzo ogólnie formułują zadania PRD, określając je jako „wspomaganie proboszcza w sprawach dotyczących całokształtu życia parafialnego": Statut parafialnej rady duszpasterskiej diecezji opolskiej, 1. W: I Synod Diecezji Opolskiej (2002-2005). Statuty i aneksy. Opole 2005. Aneks 5 s. 184.

${ }^{48}$ Por. m.in. Statut rad duszpasterskich diecezji tarnowskiej 15.09.1992. „Currenda”. R. 142: 1992 nr 10-12 s. 828-830.

${ }^{49}$ Konferencja Episkopatu Polski: Wytyczne w sprawie parafialnych rad duszpasterskich, 14. „Currenda”. R. 128: 1978 nr 5-8 s. 155. Przykłady szczegółowych zadań i inicjatyw PRD w zakresie funkcji nauczycielskiej, liturgicznej i diakonii podaje D. Li pi e c: Rola parafialnej rady duszpasterskiej $w$ budowaniu wspólnoty parafialnej. „Ateneum kapłańskie”. R. 159: 2012 nr 3 s. 551-554.

${ }^{50}$ Konferencja Episkopatu Polski, dz. cyt., 14. Dla realizacji wymienionych zadań PRD powinna uzyskiwać możliwie pełną rzeczową diagnozę stanu religijno-moralnego parafii i jej potrzeb, a także sytuacji społecznej na terenie parafii (np. ludzie chorzy i starzy, rodziny wielodzietne, rodziny rozbite, dzieci i młodzież zaniedbana itd.).

${ }^{51}$ Por. m.in. Statut parafialnych rad duszpasterskich, II. 3. W: I Synod Diecezji Rzeszowskiej (2001-2004). Rzeszów 2004 s. 289.

${ }^{52}$ Statut parafialnej rady duszpasterskiej, 8. W: IV Synod Archidiecezji Warszawskiej (19982003. Warszawa 2003. Aneks 6 s. 121.

${ }^{53}$ Statut parafialnej rady duszpasterskiej, 14. W: I Synod Diecezji Etckiej (1997-1999. Część II. Aneksy do statutów. Ełk 1999 s. 206.

${ }^{54}$ Por. m.in. Statut parafialnej rady duszpasterskiej w diecezji siedleckiej, § 3 C. „Wiadomości Diecezji Siedleckiej”. R. 2005 nr 1 s. 30.

${ }^{55}$ Podejmowanie się zadania wypracowania rocznego parafialnego planu duszpasterskiego nie stoi w żadnej sprzeczności z realizowaniem podstawowego programu Kościoła i zasadniczych priorytetów jego działania wskazanych m.in. przez Jana Pawła II w Liście apostolskim Novo millennio ineunte ( $\mathrm{nr} 29-41)$. 
całość wielość podejmowanych w parafii działań, usuwa prowizoryczność i niewłaściwą spontaniczność. Jego przygotowanie mocno angażuje członków PRD. W planowaniu, jako działalności będącej etapem przygotowawczym do podjęcia działań, wyróżnia się cztery podstawowe etapy: ustalenie celów, analizę istniejącej sytuacji, określenie czynników sprzyjających i utrudniających realizację celów, opracowanie planu czyli wybór przyszłych działan, wraz z określeniem czasu ich trwania, podziału odpowiedzialności i okresowej rewizji planu ${ }^{56}$. Wypracowanie rocznego planu duszpasterskiego $\mathrm{w}$ parafii polega $\mathrm{z}$ jednej strony na umiejętnym włączeniu $\mathrm{w}$ istniejące formy duszpasterstwa parafialnego tematyki i treści związanych z inicjatywami ogólnokościelnymi ${ }^{57}$, z programem duszpasterskim Kościoła w Polsce i z przedsięwzięciami diecezjalnymi, a z drugiej dokonuje się przez podjęcie nowych inicjatyw, których te programy koniecznie się domagają $^{58}$.

Doniosłość opracowania rocznego planu duszpasterskiego wynika także z faktu, że są z nim powiązane pozostałe szczegółowe zadania przypisane radom duszpasterskim. Praca nad przygotowaniem takiego planu jest zadaniem bardzo angażującym, domagającym się współpracy i znalezienia właściwych i skutecznych form jego realizacji w ramach podstawowych funkcji Kościoła podejmowanych w parafii w rożnych obszarach i środowiskach. Wkład jaki mogą wnieść wierni świeccy w jego przygotowanie pozwoli m.in. uwzględnić te sprawy, które nieraz są niedostrzegane przez duchownych. Całe to zadanie można słusznie uznać za bardzo dobry sposób, przy pomocy którego będzie rozwijać się współpraca między duchownymi i świeckimi.

\section{Wspólne wypracowywanie decyzji}

Przezwyciężenie trudności jakie niesie ze sobą instytucja głosu doradczego i jego stosowanie wymaga $\mathrm{w}$ większości przypadków podjęcia dwóch zasadniczych kroków. Jednym z nich jest poznanie na czym polega głos doradczy i jakie jest jego znaczenie i wartość w Kościele. Drugim krokiem jest praktyczne stosowanie i wykorzystywanie właściwie pojmowanej kościelnej doradczości dla podejmowania decyzji. Ten drugi sposób okazuje się czasem wystarczający, tak że wierni doświadczając w praktyce wartości przyznanego im głosu doradczego,

${ }^{56}$ M. O 1 s z e w s k i: Planowanie duszpasterskie. W: Leksykon teologii pastoralnej. Red. R. K a miń ski, W. Przy g o d a, M. F i ałk o w s ki. Lublin 2006 s. 619-621.

${ }^{57}$ Np. ,Rok Wiary” w roku duszpasterskim 2012/2013.

${ }^{58}$ PRD podejmując się wypracowania planu duszpasterskiego dla parafii może też iść nieco inną drogą, na której dokonuje się weryfikacja i odnowa istniejących form i sposobów działalności pasterskiej oraz wprowadzanie nowych. Wtedy jednak przygotowanie rocznego planu podejmowane jest ze świadomością, że stanowi on etap dłuższej drogi, u początku której stoi określona wizja parafii, która ma być realizowana - M. P o l a k: Planowanie duszpasterskie w parafii. Ogólnopolskie i diecezjalne plany pastoralne $w$ relacji do programów parafialnych, „Teologia Praktyczna”. T. 9: 2008 s. 94-97. 
są w stanie owocnie współpracować z proboszczem, nawet bez teoretycznego poznania, jak należy prawidło odbierać ów głos w Kościele. Natomiast na niewiele się przyda poznanie przez członków rady uzasadnień teologicznych dla głosu doradczego, jeśli w praktyce, ze strony proboszcza, zabraknie takiego właśnie rozumienia i wykorzystania doradczości, a skupi się on jedynie na słusznie przyznanym mu głosie decyzyjnym.

Na czym zatem polega głos doradczy, i dlaczego wierni mogą i powinni doradzać proboszczowi, aby w ten sposób wnosić swój wkład w ożywianie działalności pastoralnej w parafii? Otóż, najpierw należy podkreślić, że wierni świeccy doradzają kapłanom nie tyle dlatego, że są ekspertami, i że dobrze się znają na zasadach organizacji duszpasterstwa, jego formach etc. Motyw jest inny: teologiczny. Wierni mają prawo i obowiązek doradzać dlatego, że są ochrzczeni i obdarzeni darami Ducha Świętego w sakramencie bierzmowania. Ponadto są oni obdarzeni różnymi charyzmatami, zarówno tymi niezwykłymi, jak i tymi bardziej zwyczajnymi i szerzej rozpowszechnionymi ${ }^{59}$. Po drugie, należy zauważyć, że z faktu iż rady stanowią organizmy komunii kościelnej wynika jasno, że nie można zwyczajnie i jedynie powiedzieć, że proboszcz jest wolny w pójściu za opinią rady lub też nie. Oczywiście jest wolny, ale jednocześnie musi wiedzieć i rozumieć, że w radzie spotykają się dwie zasady współistniejące w komunii Kościoła: zasada hierarchiczna (Kościół jest komunią hierarchiczną) oraz zasada wspólnotowa (Kościół jest communio fidelium). Dlatego proboszcz prowadzi do wspólnego poszukiwania rozwiązań, i przyjmuje na koniec odpowiedzialność za tę decyzję, która po wysłuchaniu wszystkich, wydaje się najbardziej użyteczną i zgodną z celami, do których dąży wspólnota parafialna. W takim szerszym spojrzeniu, głos doradczy ujawnia się jako istotna część procesu decyzyjnego ${ }^{60}$. Dlatego też kodeksowa norma stanowiąca, że rada posiada głos doradczy nie powinna, i w rzeczywistości nie może być traktowana jako znaczące zredukowanie efektywnego wykonywania współodpowiedzialności, a w praktyce jako wyłączenie z procesu podejmowania decyzji w Kościele. „Doradzanie kościelne” posiada zawsze mocny wpływ na podejmowanie decyzji. Inaczej można to jeszcze wyrazić w ten sposób, że proboszcz podejmuje na koniec decyzję, ale nie byłoby takiej czy innej jego decyzji, gdyby nie wcześniejsza dyskusja i wnioski, do których dochodzą członkowie rady ${ }^{61}$.

59 Por. A. B orras: Petite apologie du conseil pastoral de paroisse. "Nouvelle revue théoloqique". R. 114: $1992 \mathrm{nr} 4$ s. 566.

${ }^{60}$ Por. R. T. K e n n e d y: Shared responsability in ecclesial decision-making, "Studia Canonica". R. 14: 1980 s. 8-9.

${ }^{61}$ Por. A. B o r r a s: La parrocchia. Diritto canonico e prospettive pastorali. Bologna $1997 \mathrm{~s}$. 226. Autor zauważa, że tylko sam proboszcz może podejmować decyzje, ale nie może być sam w ich przygotowaniu. Wszyscy bowiem członkowie parafialnej rady duszpasterskiej biorą udział w wypracowaniu decyzji, ale nie wszyscy ją podejmują. Czyni to bowiem ten, któremu powierzona jest parafia. 
Kiedy jednakże zdarzyłoby się, że proboszcz podjąłby decyzję inną niż zdanie całej rady, wówczas powinien to uzasadnić. Nie jest to wymóg prawny, ale wymóg duszpasterski i moralny. W sytuacji trudnej, gdy rozbieżności są duże, warto wówczas - jeśli to możliwe - odłożyć podjęcie decyzji i wrócić do sprawy na następnym spotkaniu. Dodatkowy czas pozwala bowiem „poradzić się” Boga w tej sprawie, raz jeszcze wszystko rozważyć, aby dość do rozwiązania, które będzie podzielane, lub przynajmniej rozumiane.

Należy zatem stwierdzić jednoznacznie, że termin „głos doradczy” wyklucza z jednej strony błędną ideę, że najlepsza decyzja na polu kościelnym rodzi się na bazie większości demokratycznej, a z drugiej, wskazuje że owa doradczość ma charakter teologiczny, który wpisuje się w realizację komunii Kościoła.

\section{Lepsza organizacja pracy PRD}

W celu udoskonalenia współpracy między duchownymi i świeckimi w ramach PRD należy również podjąć pracę nad ulepszeniem organizacyjnej strony ich działania, zarówno w odniesieniu do przygotowania spotkań, ich przebiegu, a także realizacji i weryfikacji działań. Nie chodzi tutaj jednak o zbiurokratyzowanie pracy rady, ale nadanie jej większego dynamizmu i szersze włączenie członków rady w różne etapy jej funkcjonowania.

Pierwszą przykładową kwestią do podjęcia jest odpowiednie przygotowanie spotkań rady. Najczęściej stosowanym sposobem informowania radych o najbliższym posiedzeniu PRD jest podanie takiego komunikatu w ramach ogłoszeń duszpasterskich $\mathrm{w}$ niedzielę poprzedzającą spotkanie. Co prawda, członkowie PRD są $\mathrm{w}$ ten sposób informowani o dacie posiedzenia $\mathrm{z}$ pewnym wyprzedzeniem, natomiast rzadziej dowiadują się czemu ono będzie poświęcone. $\mathrm{W}$ wielu wypadkach poznają tematykę spotkania dopiero podczas samych obrad. Wśród możliwych sposobów lepszego przygotowania spotkań PRD można wskazać chociażby listowne lub e-mailowe zaproszenie wysyłane 2-3 tygodnie wcześniej. Zaproszenie takie powinno koniecznie zawierać tematykę spotkania. Rozwiązanie to pozwala nie tylko łatwiej zaplanować udział w posiedzeniu rady, ale daje także możliwość wcześniejszego przemyślenia problemów i spraw, które będą omawiane. Za przygotowanie i rozesłanie zaproszeń mogą odpowiadać niektórzy członkowi rady, np. jej sekretarz ${ }^{62}$. Wskazywana wcześniej tematyka nie powinna ograniczać nigdy porządku obrad. W końcowej części spotkania powinno się zawsze znaleźć miejsce na dodatkowe sprawy podnoszone przed członków $\mathrm{PRD}^{63}$. Mogą też oni proponować zagadnienia i sprawy, które zasługują na włączenie pod obrady kolejnego posiedzenia ${ }^{64}$.

\footnotetext{
${ }^{62}$ Należy jednak pamiętać, że osobą zapraszająca powinien być zawsze proboszcz parafii.

${ }^{63} \mathrm{~W}$ diecezji kaliskiej istnieje wewnątrz PRD Sekretariat Rady, który składa się z trzech osób. Zespół ten sporzadza protokoty z posiedzeń, zbiera od członków rady sprawy, wnioski, pro-
} 
Z kwestią przygotowania spotkań łączy się zagadnienie planu pracy PRD. Ponieważ praca ewangelizacyjna i duszpasterska Kościoła w Polsce oparta jest na programie duszpasterskim, daje to możliwość zaplanowania zasadniczych tematów spotkań PRD. Oczywiście wspólnota parafialna jest żywą cząstką Kościoła, w której występują wciąż nowe, nieprzewidziane sytuacje i wyzwania domagające się refleksji PRD, tym niemniej znajomość planu pracy pozwala widzieć aktywność PRD w perspektywie określonej całości. Usuwa się w ten sposób wrażenie prowizoryczności, braku wizji i powiązania jednych działań z innymi.

Jeśli chodzi o sam przebieg posiedzeń rady, to warto zaproponować kilka pomocniczych rozwiązań, które mogą mocniej i szerzej zaangażować członków rady i wpłynąć na jakość wzajemnej współpracy. Spotkania powinny mieć swój plan, przy czym należy wystrzegać się zbytniego formalizmu w jego realizacji. Zasadniczo jednak plan spotkania ułatwia jego przeprowadzenia ${ }^{65}$. Przewodniczącym rady jest proboszcz, ale przewodniczenie posiedzeniem może on powierzyć swojemu zastępcy ${ }^{66}$. Niektórzy członkowie rady, uprzednio poinformowani i przygotowani, mogą wprowadzić pozostałych radnych w omawianą tematykę. Jest to bardzo dobry punkt wyjścia do dyskusji i wypracowywania postulatów działania. Na pojedyncze posiedzenia tematyczne można zaprosić eksperta z zewnątrz, który lepiej naświetli jakieś zjawisko czy problem.

Spotkania rady, nawet te najbardziej owocne, domagają się wprowadzenia $\mathrm{w}$ życie postanowień i podjętych inicjatyw. W tym celu trzeba m.in. ustalać, w jaki sposób, i kto będzie szczególnie odpowiedzialny za poszczególne działania czy jego etapy. Dziełu weryfikacji służą także protokołowanie i odczytywanie protokołu, a także powracanie po jakimś czasie do wcześniejszych ustaleń. Po zakończonym roku duszpasterskim warto podjąć refleksję nad skuteczno-

pozycje do programu najbliższego posiedzenia i przedstawia je proboszczowi; prowadzi archiwum; opracowuje tekst komunikatu z posiedzenia rady, który po aprobacie proboszcza powinien być podany do wiadomości parafian: Parafialna Rada duszpasterska. W: I Synod Diecezji Kaliskiej (2007-2009) nr 137. Kalisz 2009 s. 30.

${ }^{64}$ Por. m.in. Konferencja Episkopatu Polski, dz. cyt., 20.

${ }^{65}$ Jako przykład i propozycję można wskazać na przygotowywane przez Wydział Duszpasterstwa Ogólnego diecezji tarnowskiej konspekty spotkań PRD na cały rok duszpasterski (4 spotkania $\mathrm{w}$ ciągu roku). Ich zaleta jest m.in. to, że zawierają tematy związane ściśle $\mathrm{z}$ programem roku duszpasterskiego. Por. m.in. „Bąźmy świadkami miłości”. Konspekty spotkań parafialnej rady duszpasterskiej na rok duszpasterski 2009/2010. Tarnów 2009. Konspekty zawierają m.in. następującą propozycję przebiegu posiedzenia rady: modlitwa do Ducha Świętego; odczytanie sprawozdania z poprzedniego spotkania; fragment Pisma Świętego; wprowadzenie do dyskusji; pytania do dyskusji odnoszące się do analizy sytuacji i konkretnych działań; dyskusja; podsumowanie dyskusji; sformułowanie zadań duszpasterskich parafii w świetle omawianego tematu; wolne wnioski; modlitwa końcowa.

${ }^{66}$ Tamże. 
ścią i owocnością realizowanych inicjatyw i przedsięwzięć, oraz nad czynnikami, które ułatwiły bądź utrudniły ich realizację.

Sprawie lepszej organizacji pracy PRD służy też bez wątpienia powołanie w jej ramach specjalnych sekcji, komisji czy zespołów zajmujących się szczegółowymi dziedzinami duszpasterstwa ${ }^{67}$. Znaczna część statutów przewiduje taką możliwość. Jest ona do zrealizowania przy odpowiednio licznej radzie. Działalność sekcji sprawia, że działania PRD lepiej wpisują się w podstawowe funkcje Kościoła. Warto też zauważyć, że działalność w mniejszym zespole sekcyjnym domaga się większej odpowiedzialności i większego zaangażowania.

Kiedy przed laty promowano na ulicach Rzymu zaangażowanie misyjne katolików posługiwano się m.in. plakatem z wypisanym hasłem: Quando la Chiesa prende la coscienza di se stessa, diventa missionaria ${ }^{68}$. Parafrazując tamte słowa można powiedzieć: kiedy wszyscy wierzący: duchowni, osoby życia konsekrowanego i wierni świeccy uświadamiają sobie, że Kościół jest komunią i kierują się duchowością komunii, wtedy mogą powstawać i skutecznie działać struktury komunijne. Znajomość i umiejętność wcielania w życie soborowej eklezjologii komunii jest istotnym warunkiem dla wzajemnej współpracy w ramach PRD.

Doskonalenie wzajemnej współpracy pomiędzy duchownymi i świeckimi w tej strukturze, wskazane jako jeden $\mathrm{z}$ kilku celów tegorocznego programu duszpasterskiego Kościoła w Polsce, jest zadaniem ważnym i potrzebnym ${ }^{69}$. Będzie to służyć wszystkich, którzy ją tworzą, a jeszcze bardziej wspólnocie parafialnej, w której istnieje ona i działa. Nie należy dać się zwieść iluzji doskonałej współpracy pozbawionej cienia najmniejszych trudności, ale nie jest też dobrze, kiedy występujące problemy prowadzą do pozostawania w okopach własnych pozycji.

W artykule przedstawiono wybrane trudności we wzajemnej współpracy i możliwe sposoby ich przezwyciężenia. Wymagają one wysiłku z jednej i drugiej strony. Powinien on być podejmowany w duchu papieskiej wypowiedzi: Jeśli zatem mądre prawodawstwo, ustanawiając ścisłe reguly wspótdziatania uwypukla hierarchiczna strukturę Kościoła oraz zabezpiecza przed pokusa samowoli $i$ bezpodstawnymi żadaniami, to duchowość komunii ożywia właściwa sobie treścia formę instytucjonalna, zalecając postawę zaufania i otwartości, która respektuje w petni godność i odpowiedzialność każdego członka Ludu Bożego (NMI 45).

\footnotetext{
${ }^{67}$ Mogą to być np. sekcje: liturgiczna, ds. ewangelizacji, ds. charytatywnych, ds. duszpasterstwa młodzieży itp.

${ }^{68}$ Kiedy Kościót uświadamia sobie czym jest, staje się misyjny.

${ }^{69} \mathrm{~W}$ adhortacji Christifideles laici J a n P a w e 1 I I wskazał, w odniesieniu do diecezjalnej rady duszpasterskiej, że zasadę współpracy należy stosować szerzej i odważniej (nr 25).
} 